\title{
Hardware-in-the-Loop simulation applied to roadheader cutting head speed control system testing
}

\begin{abstract}
This paper presents a description of the test stand and results of the Hardware-in-the-Loop simulation for the angular speed control system of roadheader cutting heads. The system has been implemented in the LabView package using National Instruments $c R I O$ and $c D A Q$ devices. The system uses a discrete PI controller implemented with a cRIO FPGA module. Some results of simulation tests undernormal operating conditions and in emergency conditions have been presented.
\end{abstract}

Key words: roadheader, angular speed control, Hardware-in-the-Loop simulation

\section{INTRODUCTION}

The cutting head load of aroadheader during mining operation is a complex phenomenon dependent on a number of factors. The optimization of this process with respect topower consumption reduction and dynamic load reduction requires the identification ofindividual factors and their influence on the roadheader's performance. The most-influencing factor is cutting thickness; this depends on the location of the individual knives on the cutting head,the angular speed of the head, and the horizontal and vertical tilts. In the currently used roadheaders, the cutting head angular speed is not adjustableand the tilt is controlled manually. Automation of this process requires the use of appropriate closed-loop control systems. Selection of the structures and parameters of these systems can be made by analytical or simulation methods, but the practical implementation of such a control system using a suitable controller with specialized control software requires previous verification of its correct operation. One method of this verification may be the Hardware-in-the-Loop (HIL) simulation.

\section{THE ROLE OF HARDWARE-IN-THE-LOOP SIMULATION IN DESIGN PROCESS OF CONVERTER-FED DRIVE SYSTEMS}

The functional properties of today's electromechanical drive systems with digitally controlled power electronics are largely determined by their control software [1]. The development and testing of this control software plays a vital role in the design of adrive system. However, simulation studies that do not take into account the specific properties of the target digital system implementing the control algorithmare not able to detect certain phenomena that may play a negative role in the later functioning of the entire system. The discrepancy between the performance of the algorithm at the computer simulation level and its real-time performance (e.g., related to the speed limits of control program execution, limited signal transfer rate, memory capacity constraints, or range and precision constraints of the variables used by control algorithms) may lead to damage or destruction of the controlled machinein extreme cases (e.g., caused by instability of the control system). Disclosure of these phenomena only at the stage of 
testing the complete solution can involve considerable time and cost and even risk to health and human life [2]. Hence, Hardware-in-the-Loop techniques utilizing areal controller and computer-simulated model of the controlled object [3] are becoming increasingly important. This method can be considered as an intermediate solution between simulation studies in a uniform programming environment (e.g., Matlab/ Simulink or Scilab/Scicos) and experimental studies using real controller and real object $[4,5]$. This relationship has been shown in Figure 1.

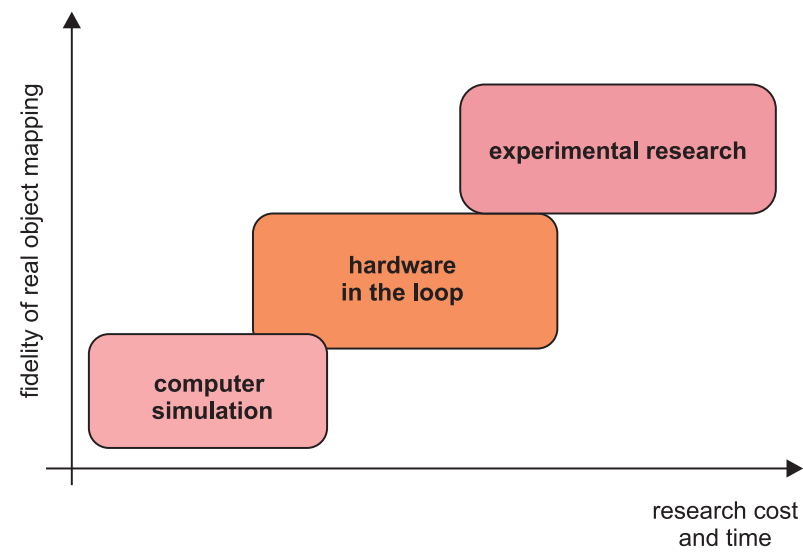

Fig. 1. Comparison of Hardware-in-the-Loop simulation with other converter-fed drive systems research methods (based on [1])

Both the controller algorithm and controlled object model are separately implemented in the form of periodically executed software loops. Between these loops, there is a continuous exchange of data. This data maps the internal state and output signal state of the controlled object as well asthe control signals generated by the controller algorithm [6]. This process has been shown schematically in Figure 2 .

The advantage of such a solution is the possibility of the relatively easy and rapid testing of the actual response of the control system to anticipated emergency situations, such as exceeding the range of allowable output values, disturbances in signal transmission, or some sensor malfunction. Verification of the real control system and developed software operation based on the mathematical model of the controlled object can significantly facilitate and shorten the entire system start-up process after the controller has been connected to the actual actuators, sensors, and controlled object [3].

Hardware-in-the-Loop tests can therefore be viewed as real-time validation of the results of the synthesis of the control algorithm developed at the
Model-in-the-Loop (MIL) level. The MIL level coverstheimplementation of the control algorithm, mathematical model of the controlled object, and mathematical models of the actuators and sensor dynamics in a uniform hardware and software environment based on relationships developed through theoretical analysis or experimental identification.

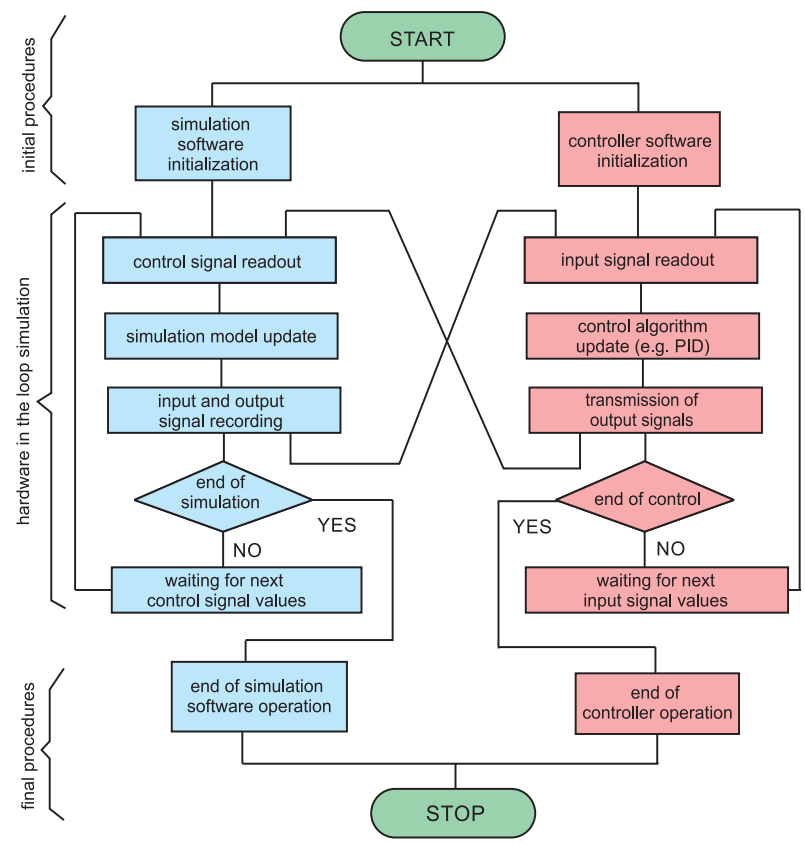

Fig. 2. Simulation process using Hardware-in-the-Loop method

\section{LABORATORY STAND FOR TESTING CONTROL SYSTEM OF ROADHEADER CUTTING HEAD DRIVE SYSTEM USING HARDWARE-IN-THE-LOOP SIMULATION METHOD}

\subsection{Structure of test stand}

A closer approximation of the realoperating conditions of acontrol system is possible with the HIL method and is based on the application of the target controller with the developed software, connected to the mathematical model of the controlled plant executed on a separate hardware platform. An important feature of this method is that the nature of the input and output signals and their changes are similar to the measurement and control signals occurring under real-time and real-operating-environment conditions. Based on previously developed and identified 
models of the converter-fed drive system dynamics used in pure simulation research of the cutting head angular velocity control system using themodel-in-the-loop (MIL) technique, a laboratory stand has been developed for the control circuits and software using the Hardware-in-the-Loop (HIL) technique. The purpose of developing such a system is related to the ability to test the implementation of the relevant real-time control algorithms with the target industrial controller and input and output signals close to reality. The developed concept of the HIL test stand is based on two main hardware components: a target real-time controller intended to be used in the final system, and a PC-based simulation model of the controlled object developed using LabView ${ }^{\mathrm{TM}}$ software. The controlled object model imitates a roadheader cutting head converter-fed drive system together with the model of the load process. The schematic diagram of the circuit is shown in Figure 3. As shown in Figure 3, the hardware interface between the controller and PC computer is the National Instruments cDAQ-9174 device [7] with the appropriate analog input and output cards. On the basis of the accepted conceptual assumptions described above, an automated test stand for the cutting head speed control system has been designed and completed for use of the HIL method.

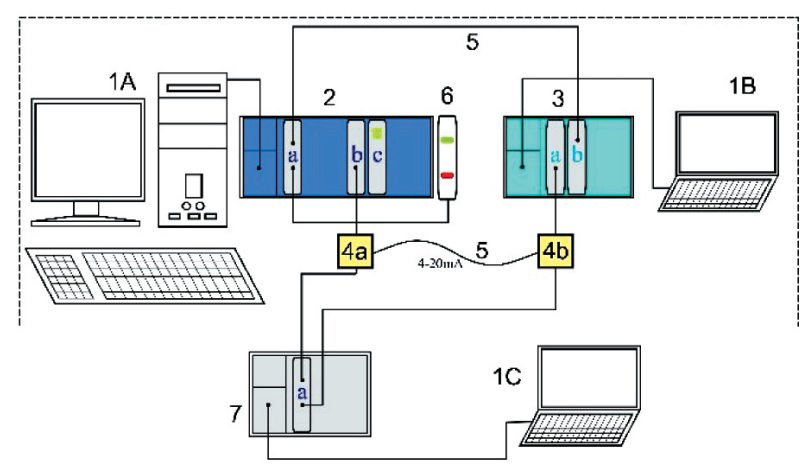

Fig. 3. Schematic diagram of laboratory standfor

HIL testing of cutting head speed control system of roadheader

The basic elements of the developed HIL test stand shown in Figures 3 and 4 are as follows:

1) personal computers designed to work with $\mathrm{Na}$ tional Instrument control and measurement devices: $1 \mathrm{~A}$ connected toa cRIOreal-time PI controller; $1 \mathrm{~B}$ connected to $\mathrm{CDAQ}$, acting as an object simulator; $1 \mathrm{C}$ connected to $\mathrm{CDAQ}$, designed for acquisition, recording, and visualization of measurement data;
2) NI cRIO-9074 controller (2) with analog input card (a), analog output card(b), and digital output card (c);

3) NI cDAQ-9174 (3) interface with analog input card (a) and analog output card (b);

4) voltage conversion circuit from $0-10 \mathrm{~V}$ to current standard 4-20 mA (4A) with an open-loop alarm and a simple current-voltage converter (4B);

5) shielded cables for transmission of control and measurement signals (5);

6) Fael LP322 switch (6) with normally closed unstable contact as an element designed to reset the protection against the effects of loss of control capability;

7) NI cDAQ-9174 (7) interface with an analog input card;

8) power supplies of the individual NI control and recording devices.

The NI cRIO-9074 (2) controller [8] has been intended for an operation in the final version of the angular speed control system of the roadheader cutting heads. The 32-channel 16-bit NI 9205 analog input module with a voltage range of $\pm 10 \mathrm{~V}$ and a maximum sampling rate of $250 \mathrm{kS} / \mathrm{s}$ is used as the controller input [9]. The controller output has been implemented using an NI 9263 four-channel analog output module with a voltage range of $\pm 10 \mathrm{~V}$ and maximum total sampling rate of $100 \mathrm{kS} / \mathrm{s}$ for all channels [10]. The cDAQ-9174 (3) 4-channel NI 9215 analog output module with a voltage range of $\pm 10 \mathrm{~V}$ and a maximum total sampling rate of $150 \mathrm{kS} / \mathrm{s}$ divided by all channels and an identical analogue output module (as in the cRIO controller) have been used for the hardware modeling of the real controlled object. Additionally, the NI 9474 series digital output card has been used to signal a possible emergency condition. An overall view of the laboratory test stand is shown in Figure 4.

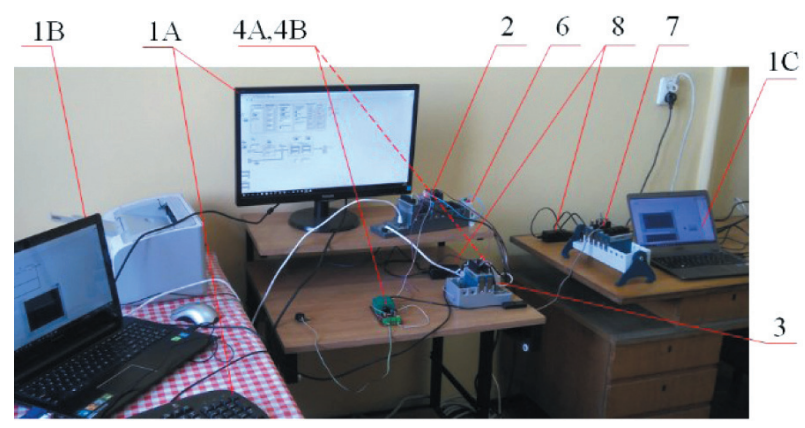

Fig. 4. Overall view of laboratory stand for HIL method control system testing 


\subsection{Transmission of control signal between controller and controlled object model}

One of the important factors determining the correct operation of the control system is the transmission of the control signal from the controller to the actuator. This transmission must be performed in a reliable manner (i.e., insensitive to disturbances) and must be adapted to the structure of the regulation system in terms of dynamics (frequency and periodicity of signal transmission) and to the distance between the controller and actuator. This method must also be adapted to the controller's ability to generate the output signal and signal the input capabilities of the actuator - in this case, the frequency inverter (equipped with an analog control input). Therefore, for transmission of the control signal, the 4-20 mA current loop standard has been chosen because - due to the higher output impedance of the signal transmitter and the lower input impedance of the receiver - it is much more immune to electromagnetic interference than the transmission of the voltage signal. Limiting the output signal domain to the 4-20 mA range makes it easy to detect a current loop break (i.e., loss of control signal) resulting in theloss of system controllability. In this case, the frequency inverter is quickly switched off,and the emergency event is properly signaled. The current loop interface has been implemented using the Analog Devices AD694 transmitter.Thisenables the conversion of a voltage signal from arange of $0-10 \mathrm{~V}$ (which corresponds to the output voltage level of the NI 9263 card) to a current signal of 4-20 mA with a nonlinearity lower than $0.002 \%$ [11]. This device features an open loop detection system and internal 2,000 V and $10,000 \mathrm{~V}$ reference voltage sources.

\section{TEST RESULTS \\ OF ROADHEADER CUTTING HEAD DRIVE SPEED CONTROL SYSTEM WITH HIL METHOD}

\subsection{Results of angular velocity control tests of cutting heads under load torque changes}

The mounted and tested laboratory stand has been used for a number of real-time studies of the angular speed control system for roadheader cutting heads undercontrolled dynamic and static overload conditions, taking into account the real operating conditions of the machine and possible occurrence of emergency conditions. The target speed controller has been implemented in the NI cRIO-9074 controller using the FPGA module $[12,13]$. The FPGA module has a unidirectional signal flow (without any software-based loops), so it complies with the requirements concerning the speed and reliability of the real-time system performance. The simulation model of the roadheader with the frequency inverterfed drive system has been implemented using the NI cDAQ-9174. The Front Panel of this simulation model is shown in Figure 5.

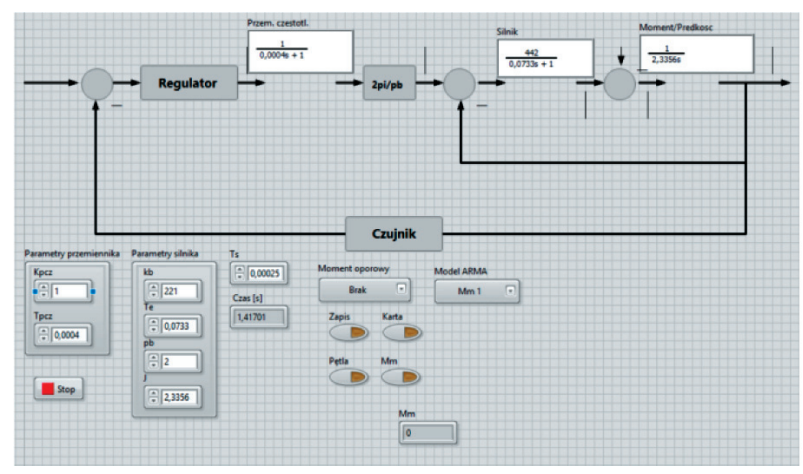

Fig. 5. Screenshot of Front Panel of road header drive simulation model

The input and output signal values have been recorded by a separate NI cDAQ device (pos. 7 in Figs. 3 and 4) programmed in LabView. The Front Panel of the recording program is shown in Figure 6.

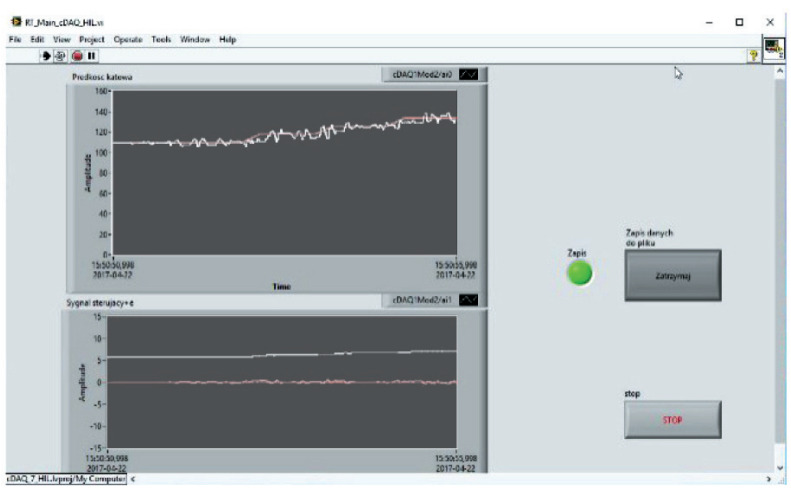

Fig. 6. Screenshot of Front Panel of recording software during example test of angular velocity control system with HIL method

Figure 7 shows the test results of a system with a load torque pattern programmed on the basis of 
data directly recorded during an operation of the real shearer (total load torque caused by friction and rock-cutting forces).
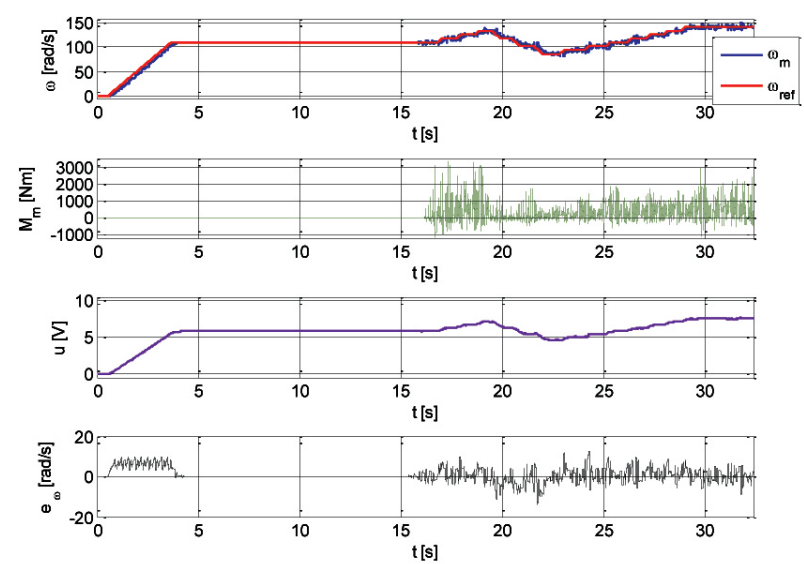

Fig. 7. HIL tested waveforms of reference and real angular velocity ofroadheader drive model loaded with torque restored from directly recorded load patterns

The next stage of the research involved the operation of the system with different load torque values generated by the ARMA model with coefficients identified from the experimental studies. The results of an example simulation are shown in Figure 8.
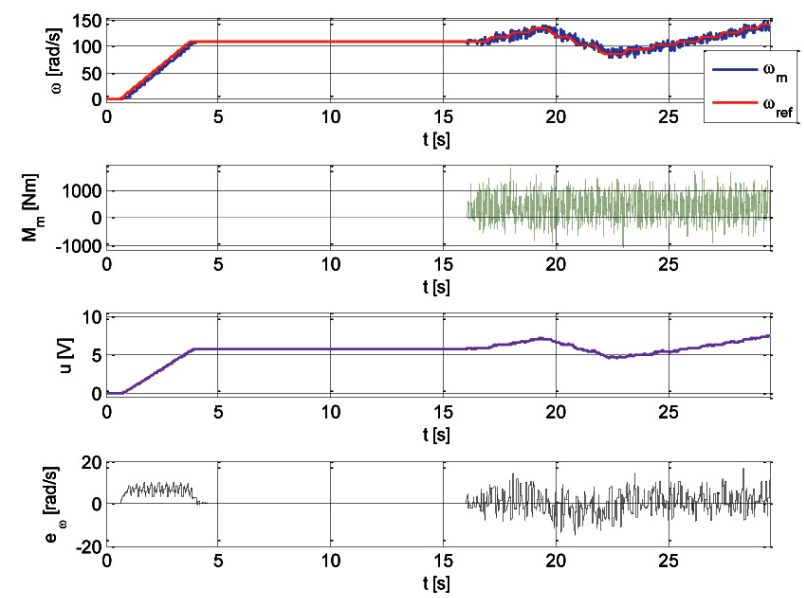

Fig. 8. HIL tests of reference value and angular velocity of roadheader drive model loaded with torque in form of time sequence generated using ARMA model

\subsection{HIL test results of protection system against effects of emergency conditions}

One of the important goals of the HIL simulation tests is to check the response of the software to possible emergency situations. These situations must be properly handled. Emergency conditions involve the loss of controllability; examples include the following situations:

- disappearing or interfering signals from the sensors (e.g., speed sensor),

- loss or disturbance of control signal transmission to actuators (e.g., frequency inverter),

- loss of system stability (i.e., oscillations of output values due to system divergence),

- operation of internal overcurrent protection in the actuator (frequency inverter).

Selected emergency states have been simulated on a test workbench. In the course of the test, the operation of the software safety module has been checked in case of an open loop break in the continuity of the control circuit, both in the control and feedback paths. The response of the protection system to the disappearance of the speed signal in the feedback loop is shown in Figure 9. A loss of system stability was achieved by incrementally increasing the value of the controller gain during system operation. The loss of system stability can be characterized by increasing high magnitude speed oscillations. As a criterion for detecting the fault state, exceeding the limit value of the deviation between the reference and actual speed value has been established. In each of the mentioned emergency states, the controller response should lead to zero control signal. It should also be possible to signal an emergency and exclude the possibility of direct reactivation of the control system in the event of an unrepaired failure. The response of the protection system to the loss of stability during system start-up is shown in Fig. 10, and the response of the control system to the loss of stability at the load torque is shown in Figures 11 and 12.
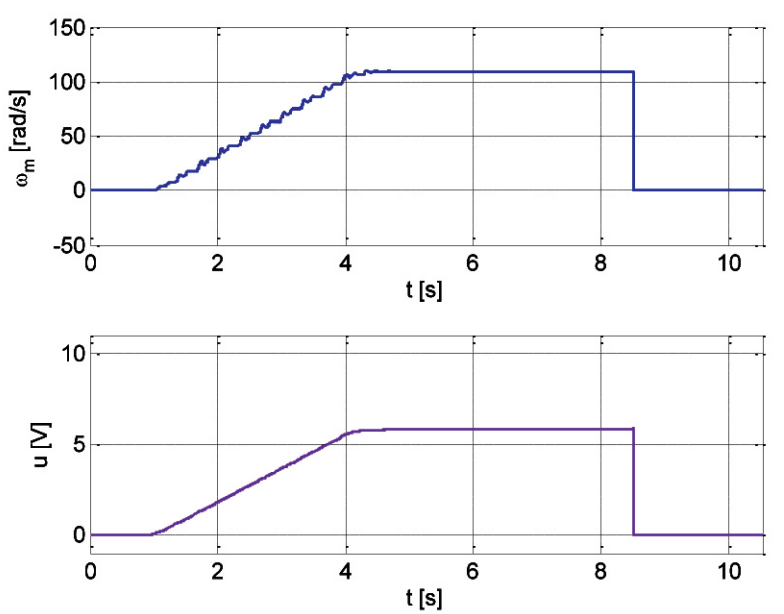

Fig. 9. Changes of angular speed $\omega_{m}$ and control signal $u$ over time when feedback loop is broken (signal loss from speed sensor) 

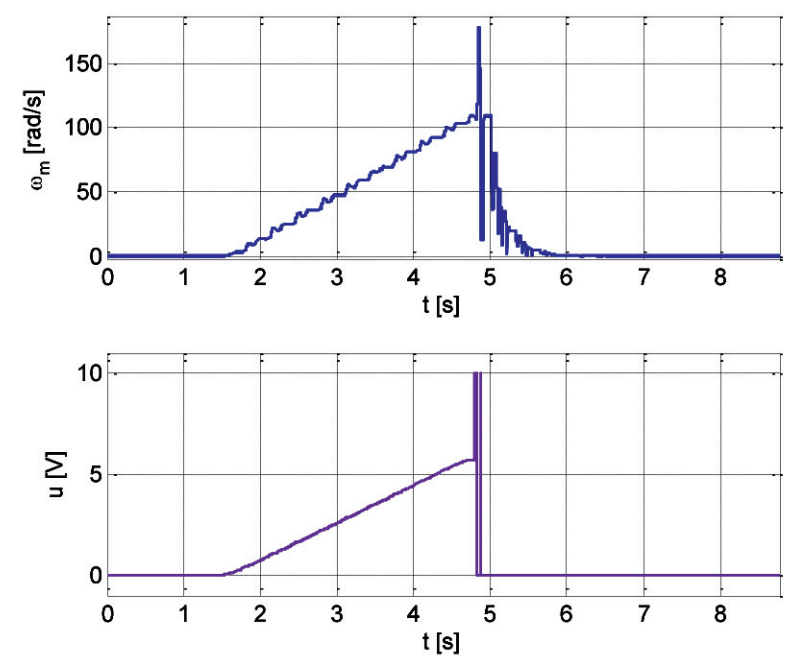

Fig. 10. Changes of angular speed $\omega_{m}$ and control signal $u$ over time incase of detected speed oscillations due to loss of stability during start-up of drive
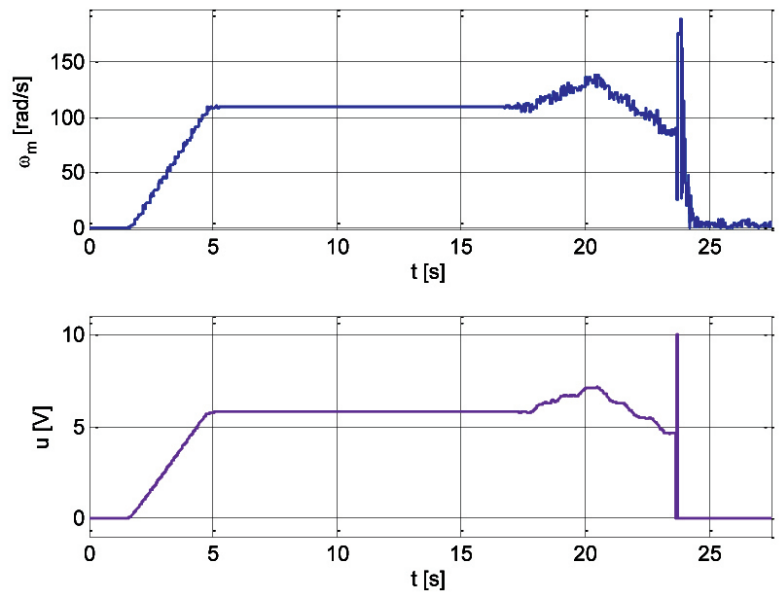

Fig. 11. Changes of angular speed $\omega_{m}$ and control signal $u$ over time incase of detected speed oscillations due to loss of stability with decreasing load conditions
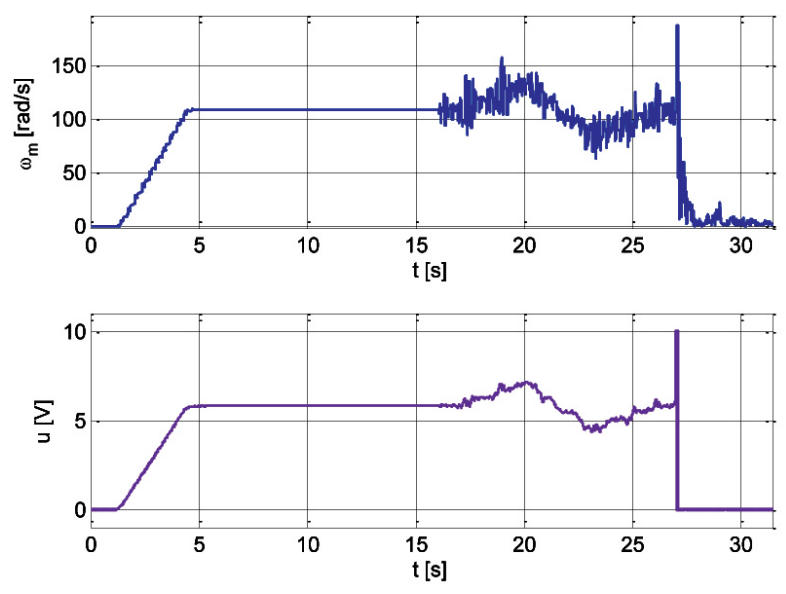

Fig. 12. Changes of angular speed $\omega_{m}$ and control signal $u$ over time incase of detected speed oscillations due to loss of stability with increasing load conditions

\section{CONCLUSIONS}

The behavioral results of the discrete-PI controller (with gains tuned by an earlier MIL simulation method) implemented in the cRIO controller and interfacing with the digital simulation model of the roadheader cutting head drive system show a significant similarity toprevious MIL results. Also, the implemented protection algorithms against the effects of emergency conditions demonstrated their efficiency, responding quickly to the disruptions and breakdowns that can occur during the operation of aroadheader. This proved the correctness of the development of the adopted control algorithm and its software implementation, applied to acontroller intended for operation in areal system.

\section{Acknowledgements}

This work was implemented under the research project entitled "Control of roadheader cutting heads movement for reduction of energy consumption of mining and dynamic loads" co-financed by the National Center for Research and Development under the Applied Research Projects (agreement no. PBS3/B2/15/2015).

\section{References}

[1] Sarhadi P., Yousefpour S.: State of the art: hardware in the loop modeling and simulation with its applications in design, development and implementation of system and control software, "International Journal of Dynamics and Conrol" 2015, 3: 470-479.

[2] Jaszczak S.: Procedura Hardware-in-the-Loop w syntezie algorytmów sterowania, "Pomiary - Automatyka - Kontrola" 2010, 56, 7: 685-687.

[3] Pietrusewicz K.: Projektowanie mechatroniczne. Technika Hardware-in-the-Loop a założenia Industry 4.0, "Napędy i Sterowanie" 2016, 4: 92-98.

[4] Bouscayrol A.: Hardware-in-the-Loop simulation, Industrial Electronics Handbook, 2nd ed., Vol. 3, Chapter 35, Taylor \& Francis, Chicago 2011.

[5] Bouscayrol A.: Hardware-in-the-Loop simulation, Electric Vehicle Symposium EVS'24, Stavanger 2009.

[6] Maclay D.: Simulation gets into the loop, "IEEE Review" 1997, 43, 3: 109-112.

[7] NI cDAQ ${ }^{\text {TM }}$-9174 Four-Slot USB Chassis Specifications, National Instruments, 2013.

[8] NI cRIO-9074XT Reconfigurable Embedded Chassis with IntegratedIntelligent Real-Time Controller, National Instruments, 2016.

[9] NI 9205 Datasheet 16 AI Differential/32 AI Single-Ended, $\pm 200 \mathrm{mV}$ to $\pm 10 \mathrm{~V}, 16 \mathrm{Bit}, 250 \mathrm{kS} / \mathrm{s}$ Aggregate, National Instruments, 2015. 
[10] NI 9263 Datasheet4 AO, \pm 10 V, 16 Bit, 100 kS/s/ch Simultaneous, National Instruments, 2016.

[11] AD694 4-20 mA transmitter. DatasheetRev B, Analog Devices Inc, 2002.

[12] Ponce-Cruz P., Molina A., MacCleery B.: FuzzyLogicType 1 and Type 2 Based on LabVIEW ${ }^{\mathrm{TM}} F P G A$, Springer International Publishing, Heidelberg 2016.

[13] Baran E.D.: LabVIEW FPGA. Riekonfiguriruyemyye izmieritiel'nyyei i upravlyayushchiye sistemy, "DMK Priess", Moskva 2009.
ADAM HEYDUK, Ph.D., Eng. JAROSLAW JOOSTBERENS, Ph.D., Eng.

Department of Electrical Engineering and Automation in Industry Faculty of Mining and Geology Silesian University of Technology ul. Akademicka 2, 44-100 Gliwice, Poland \{Adam.Heyduk, Jaroslaw.Joostberens\}@polsl.pl 


\title{
Metoda Hardware-in-the-Loop w zastosowaniu do badania układu regulacji prędkości kątowej głowic urabiających kombajnu chodnikowego
}

\begin{abstract}
W artykule przedstawiono opis stanowiska badawczego oraz wyniki symulacji metoda Hardware-in-the-Loop przeprowadzonej dla układu regulacji prędkości kątowej głowic urabiających kombajnu chodnikowego. Uktad zostat utworzony w systemie LabView $z$ wykorzystaniem urzadzeń cRIO oraz cDAQ. W uktadzie zastosowano dyskretny regulator typu PI zrealizowany $z$ wykorzystaniem sterownika cRIO. Przedstawiono wyniki badań symulacyjnych $w$ stanach normalnej pracy oraz $w$ stanach awaryjnych.
\end{abstract}

Słowa kluczowe: kombajn chodnikowy, regulacja prędkości katowej, Hardware-in-the-Loop

\section{WSTĘP}

Obciążenie układu napędowego głowic urabiających kombajnu chodnikowego w trakcie urabiania jest zjawiskiem złożonym, zależnym od szeregu czynników. Optymalizacja tego procesu $\mathrm{z}$ punktu widzenia zmniejszenia energochłonności i obciążeń dynamicznych wymaga identyfikacji poszczególnych czynników wpływających na jego przebieg. Wymienić tu można przede wszystkim grubość skrawu zależną od rozmieszczenia poszczególnych noży na głowicy urabiającej oraz od prędkości kątowej głowicy, a także jej wychylenia w płaszczyźnie poziomej i pionowej. W dotychczas stosowanych kombajnach chodnikowych prędkość głowicy nie jest regulowana, natomiast wychylenia sterowane są w sposób ręczny. Automatyzacja tego procesu wymaga zastosowania odpowiednich układów regulacji, pracujących $\mathrm{w}$ zamkniętej pętli sprzężenia zwrotnego. Dobór struktury i parametrów tych układów może być dokonywany metodami analitycznymi lub symulacyjnymi, jednak praktyczna implementacja tego układu $\mathrm{z}$ zastosowaniem odpowiedniego sterownika $\mathrm{z}$ wyspecjalizowanym oprogramowaniem wymaga weryfikacji poprawności jego działania. Jedną z metod takiej weryfikacji może być symulacja Hardware-in-the-Loop (HIL).
2. ROLA SYMULACJI

HARDWARE-IN-THE-LOOP W PROCESIE PROJEKTOWANIA PRZEKSZTAŁTNIKOWYCH UKŁADÓW NAPĘDOWYCH

Właściwości funkcjonalne współczesnych układów napędowych z cyfrowo sterowanymi przekształtnikami energoelektronicznymi w istotnym stopniu określane są przez oprogramowanie [1]. Opracowanie i testowanie tego oprogramowania odgrywają zasadniczą rolę w procesie konstrukcji układu napędowego. Badania symulacyjne nieuwzględniające specyfiki docelowego układu, realizującego algorytm sterowania, nie są jednak w stanie wykryć niektórych zjawisk, mogących odgrywać negatywną rolę w późniejszym funkcjonowaniu całego systemu. Rozbieżność między działaniem algorytmu na poziomie symulacji komputerowej i w czasie rzeczywistym (związana np. z ograniczeniami szybkości realizacji programu sterującego, szybkości transmisji sygnałów, ograniczeniami pojemności pamięci czy też ograniczeniami zakresu i precyzji stosowanych zmiennych) może prowadzić, w krańcowym przypadku, do uszkodzenia lub zniszczenia obiektu z powodu np. niestabilności układu sterującego. Ujawnienie tych zjawisk dopiero na etapie 
testowania gotowego rozwiązania może wiązać się z dużymi nakładami czasu i kosztów, a nawet z zagrożeniem dla zdrowia i życia ludzkiego [2]. Stąd też coraz większego znaczenia nabierają techniki badań Hardware-in-the-Loop, wykorzystujące rzeczywisty układ sterownika i komputerowy model sterowanego obiektu [3]. Metodę tę można traktować jako rozwiązanie pośrednie pomiędzy badaniami symulacyjnymi $w$ jednolitym środowisku programowym (np. Matlab/Simulink lub Scilab/Scicos), a badaniami doświadczalnymi $\mathrm{z}$ wykorzystaniem rzeczywistego sterownika i rzeczywistego obiektu [4-5]. Zależność tę przedstawiono na rysunku 1 .

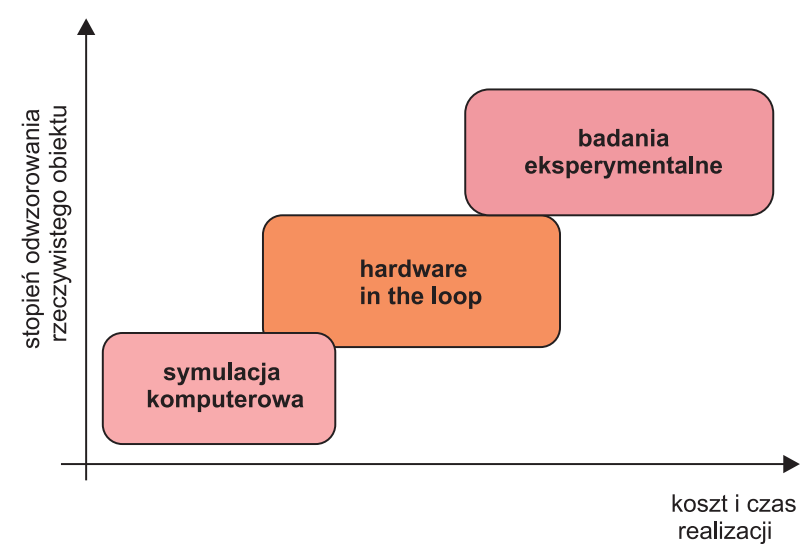

Rys. 1. Porównanie metody Hardware-in-the-Loop z innymi sposobami badań przeksztaltnikowych uktadów napędowych (wedtug [1])

Zarówno algorytm regulacji, jak i model sterowanego obiektu realizowane są w postaci cyklicznie wykonywanych pętli programowych, między którymi istnieje wymiana danych odwzorowujących stan modelu sterowanego obiektu oraz generowane przez algorytm sygnały sterujące [6]. Proces ten ukazano schematycznie na rysunku 2.

Zaletą takiego rozwiązania jest także możliwość stosunkowo łatwego i szybkiego przetestowania rzeczywistej reakcji układu sterowania w przewidywanych sytuacjach awaryjnych, charakteryzujących się np. przekroczeniem zakresu dopuszczalnych wielkości wyjściowych, zakłóceniami w transmisji sygnałów lub też błędnym działaniem niektórych czujników. Sprawdzenie działania rzeczywistego układu i oprogramowania sterującego oparte na modelu matematycznego sterowanego obiektu może w istotny sposób ułatwić i skrócić proces uruchamiania całego syste$\mathrm{mu}$ po połączeniu sterownika $\mathrm{z}$ rzeczywistymi elementami wykonawczymi, czujnikami i sterowanym obiektem [3]. Badania metodą Hardware-in-the-Loop można więc traktować jako prowadzoną w czasie rzeczywistym weryfikację wyników syntezy algorytmu sterowania zrealizowanej na poziomie Model-in-the-Loop (MIL), czyli realizacji algorytmu sterowania, modelu matematycznego obiektu sterowania oraz modeli matematycznych układów wykonawczych i pomiarowych $\mathrm{w}$ jednolitym środowisku sprzętowo-programowym w oparciu o zależności opracowane na drodze analizy teoretycznej lub identyfikacji doświadczalnej.

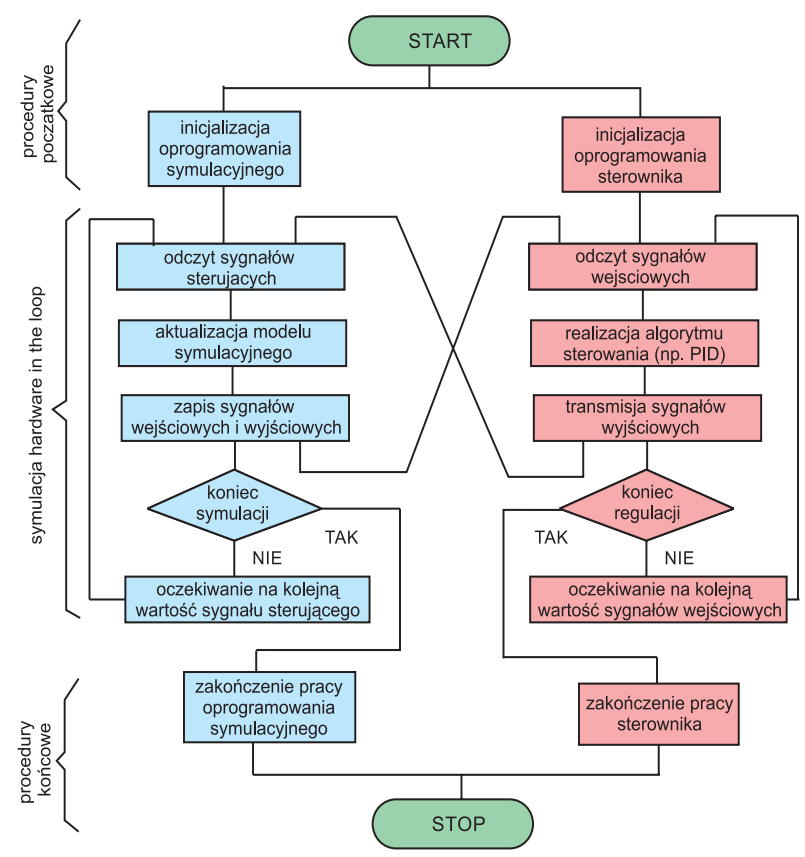

Rys. 2. Przebieg procesu symulacji z wykorzystaniem metody Hardware-in-the-Loop

\section{STANOWISKO LABORATORYJNE DO BADAŃ UKŁADU NAPĘDOWEGO GKOWIC URABIAJACCYCH KOMBAJNU CHODNIKOWEGO METODA HARDWARE-IN-THE-LOOP}

\subsection{Struktura stanowiska badawczego}

Zbliżenie się do warunków rzeczywistych, w których ma pracować układ sterowania, możliwe jest w przypadku metody HIL i polega na zastosowaniu docelowego sterownika i sprawdzeniu jego działania w układzie $\mathrm{z}$ modelem matematycznym obiektu zrealizowanym na osobnej platformie sprzętowej. Istotną cechą tej metody jest to, że sygnały wejścia i wyjścia oraz charakter zmiany tych sygnałów jest zbliżony do sygnałów pomiarowych i sterujących występujących w warunkach i czasie rzeczywistym. $\mathrm{Na}$ podstawie wcześniej opracowanych modeli dynamiki 
przekształtnikowego układu napędowego wykorzystywane $\mathrm{w}$ badaniach symulacyjnych układów regulacji prędkości kątowej głowic urabiających metodą Model-in-the-Loop (MIL), opracowano stanowisko do badań testowych układu sterowania metodą Hardware-in-the-Loop (HIL). Celowość budowy takiego układu związana jest z możliwością przetestowania stosownych algorytmów sterowania w czasie rzeczywistym z użyciem przewidzianego sterownika przemysłowego.

Opracowana koncepcja stanowiska do badań metodą HIL opiera się na dwóch głównych elementach sprzętowych: planowanym do wykorzystania w układzie docelowym sterowniku oraz utworzonym za pomocą oprogramowania LabView na komputerze klasy PC symulacyjnego modelu obiektu sterowania. Model obiektu odwzorowuje układ napędowy głowic urabiających kombajnu chodnikowego wraz z modelem ich obciążenia. Schemat ideowy układu przedstawiono na rysunku 3. Jako interfejs sprzętowy między sterownikiem a komputerem zastosowano układ NI cDAQ-9174 [7] wraz ze stosownymi kartami wejść oraz wyjšć analogowych.

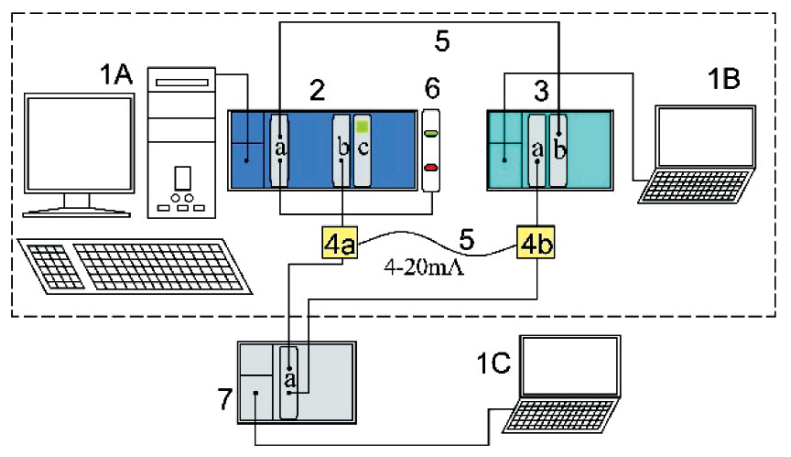

Rys. 3. Schemat ideowy stanowiska do testowania systemu sterowania napędu głowic urabiajacych

kombajnu chodnikowego metoda HIL

$\mathrm{Na}$ podstawie przyjętych założeń koncepcyjnych zostało zaprojektowane i wykonane stanowisko do badań automatycznego układu sterowania prędkości głowic urabiających z wykorzystaniem metody HIL.

Podstawowymi elementami opracowanego i wykonanego stanowiska do badania metodą HIL, pokazanymi na rysunkach 3 i 4, są:

1) komputery klasy PC przewidziane do współpracy $\mathrm{z}$ urządzeniami kontrolno-pomiarowymi firmy National Instrument - 1A komputer do współpracy ze sterownikiem cRIO, 1B - komputer do współpracy $\mathrm{z}$ cDAQ symulującym rzeczywisty obiekt, 1C - komputer do współpracy z układem cDAQ przeznaczonym do rejestracji, wizualizacji i akwizycji danych pomiarowych;
2) sterownik NI cRIO-9074 (2) z kartami: wejść analogowych (a), wyjść analogowych (b) i cyfrowych (c);

3) interfejs cDAQ-9174 (3) z kartą wejść analogowych (a) oraz kartą wyjść analogowych (b);

4) układ przetwarzający sygnał napięciowy $0-10 \mathrm{~V}$ na standard prądowy 4-20 mA (4A) z sygnalizacją przerwania pętli prądowej oraz prosty przetwornik prąd-napięcie (4B);

5) ekranowane przewody do transmisji sygnałów sterującego i pomiarowych (5);

6) łącznik Fael LP322 (6) ze stykiem niestabilnym normalnie zamkniętym jako element przeznaczony do kasowania zadziałania zabezpieczenia od skutków utraty zdolności sterowania;

7) interfejs cDAQ-9174 (7) z kartą wejść analogowych;

8) zasilacze (8) poszczególnych urządzeń rejestrująco-kontrolnych NI.

Do pracy w układzie rzeczywistym regulacji prędkości kątowej głowic przewidziany został sterownik NI cRIO-9074 (2) [8]. Jako wejście sterownika zastosowano 32-kanałowy 16-bitowy moduł wejść analogowych serii NI 9205 o zakresie napięciowym $\pm 10 \mathrm{~V}$ i maksymalnej częstotliwości próbkowania $250 \mathrm{kS} / \mathrm{s}$ [9]. Wyjście sterownika utworzono, stosując czterokanałowy moduł wyjş́ć analogowych NI 9263 o zakresie napięciowym $\pm 10 \mathrm{~V}$ oraz maksymalnej częstotliwości próbkowania $100 \mathrm{kS} / \mathrm{s}$ dzielonej na kanał [10]. Do sprzętowego zamodelowania obiektu rzeczywistego posłużył układ cDAQ-9174 (3) wyposażony w czterokanałowy moduł wyjść analogowych NI 9215 o zakresie napięciowym $\pm 10 \mathrm{~V}$ i maksymalnej częstotliwości próbkowania $150 \mathrm{kS} / \mathrm{s}$ dzielonej na kanał oraz identyczny moduł wyjść analogowych, jak w sterowniku cRIO. Dodatkowo wprowadzono kartę wyjść cyfrowych służącą do sygnalizacji wystąpienia stanu awaryjnego serii NI 9474. Widok stanowiska laboratoryjnego przedstawiono na rysunku 4.

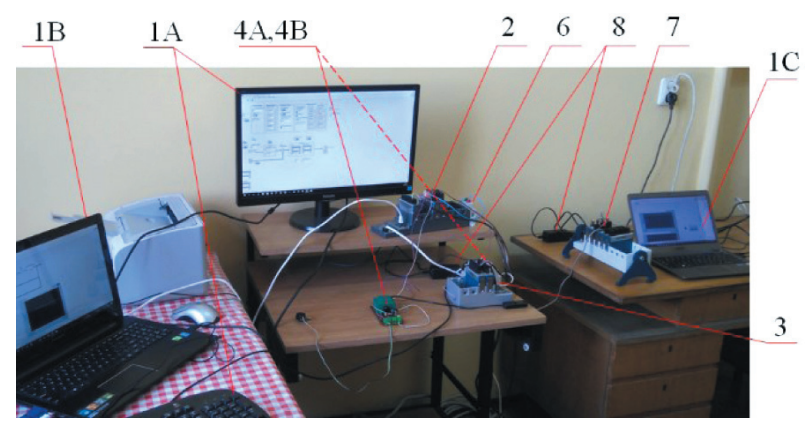

Rys. 4. Widok stanowiska do badań testowych $z$ wykorzystaniem metody HIL 


\subsection{Transmisja sygnału sterującego między sterownikiem a modelem obiektu}

Jednym z istotnych czynników decydujących o prawidłowej pracy układu sterowania jest transmisja sygnału sterującego między regulatorem a elementem wykonawczym. Transmisja ta musi przebiegać w sposób niezawodny, czyli niewrażliwy na zakłócenia oraz dopasowany do struktury układu regulacji pod względem dynamiki (częstotliwość oraz regularność przesyłania sygnału) i odległości między regulatorem a elementem wykonawczym. Sposób ten musi być również dostosowany do możliwości generowania sygnału przez regulator oraz odczytu tego sygnału przez element wykonawczy (w tym przypadku przemiennik częstotliwości wyposażony w sterownicze wejście analogowe).

Do transmisji sygnału sterującego wybrano standard pętli prądowej, gdyż ze względu na większą impedancję wyjściową nadajnika sygnału i mniejszą impedancję wejściową odbiornika jest on znacznie bardziej odporny na zakłócenia elektromagnetyczne niż przesył sygnału napięciowego. Ograniczenie zakresu przesyłanego sygnału do wartości 4-20 mA umożliwia łatwe wykrycie przerwania pętli prądowej, czyli zaniku sygnału sterującego, powodujące utratę sterowalności układu. W tej sytuacji następuje szybkie wyłączenie przemiennika częstotliwości i odpowiednia sygnalizacja zaistniałego zdarzenia. Interfejs pętli prądowej został zrealizowany z wykorzystaniem układu nadajnika AD694 firmy Analog Devices. Umożliwia on konwersję sygnału napięciowego z zakresu 0-10 V (co jest zgodne z poziomem napięć wyjściowych karty NI 9263) na sygnał prądowy 4-20 mA z nieliniowością nieprzekraczającą $0,002 \%$ [11]. Układ ten wyposażony jest $\mathrm{w}$ system detekcji sygnalizacji przerwy w linii sygnałowej oraz wewnętrzne źródła napięcia odniesienia - 2000 V i $10000 \mathrm{~V}$.

\section{WYNIKI BADAŃ STANOWISKOWYCH UKŁADU REGULACJI NAPĘDU GŁOWIC URABIAJĄCYCH METODA HIL}

\subsection{Wyniki badań regulacji prędkości kątowej głowic urabiających w warunkach zmian momentu obciążenia}

Zmontowane i przetestowane stanowisko posłużyło do szeregu badań układu regulacji prędkości kąto- wej głowic urabiających kombajnu prowadzonych w czasie rzeczywistym w warunkach kontrolowanych przeciążeń dynamicznych i statycznych, uwzględniających realne warunki pracy maszyny oraz mogące wystąpić stany awaryjne. Regulator prędkości kątowej został zaimplementowany w sterowniku NI cRIO-9074 z wykorzystaniem modułu FPGA $[12,13]$. W układzie FPGA występuje jednokierunkowy przepływ sygnałów, co spełnia wysokie wymagania dotyczące szybkości i pewności działania sterownika w czasie rzeczywistym. Model kombajnu z przekształtnikowym układem napędowym został zaimplementowany z wykorzystaniem urządzenia NI cDAQ-9174. Widok Front Panelu modelu kombajnu przedstawiono na rysunku 5.

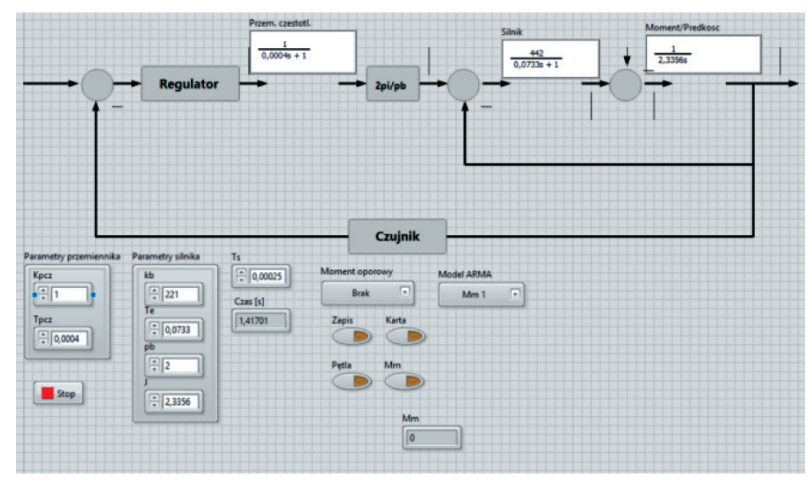

Rys. 5. Widok Front Panelu oprogramowania modelu uktadu napędowego kombajnu chodnikowego

Wartości sygnałów wejściowych i wyjściowych rejestrowane były przez odrębny układ NI cDAQ (poz. 7 na rys. 3 i 4) oprogramowany w środowisku LabView. Front Panel programu rejestrującego przedstawiono na rysunku 6.

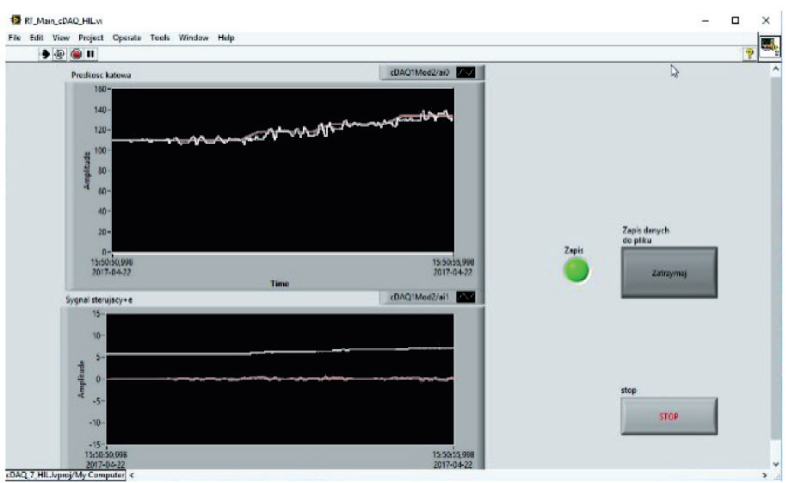

Rys. 6. Widok Front Panelu oprogramowania rejestracyjnego podczas przyktadowych testowych badań stanowiskowych uktadu regulacji prędkości kątowej głowic metoda HIL 
Na rysunku 7 przedstawiono wyniki badań układu z momentem oporowym (odzwierciedlającym opory ruchu obrotowego poszczególnych elementów układu oraz opory skrawania skały) zadawanym programowo na podstawie bezpośrednio zarejestrowanych danych.
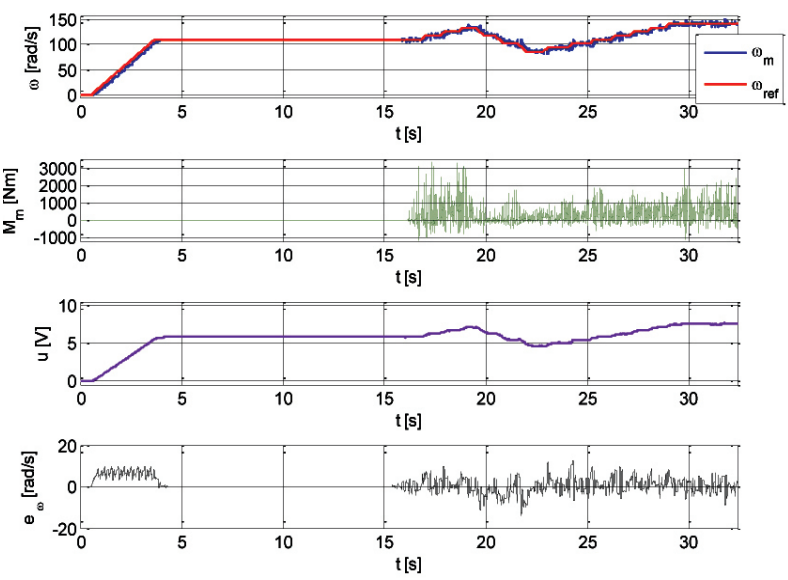

Rys. 7. Odtwarzane podczas badań metoda HIL przebiegi czasowe wartości zadanej $\omega_{\text {ref }}$ prędkości katowej $\omega_{m}$ modelu układu napędowego obciażonego momentem oporowym $M_{m}(t)$ o przebiegu bezpośrednio zarejestrowanym podczas badań stanowiskowych

Kolejny etap badań obejmował pracę układu przy zróżnicowanych wartościach momentu obciążenia wygenerowanych przez model ARMA o współczynnikach zidentyfikowanych na podstawie badań doświadczalnych. Wyniki przykładowej symulacji przedstawiono na rysunku 8.

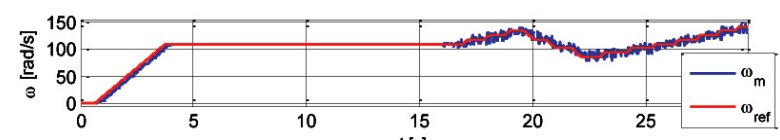

$\mathrm{t}[\mathrm{s}]$
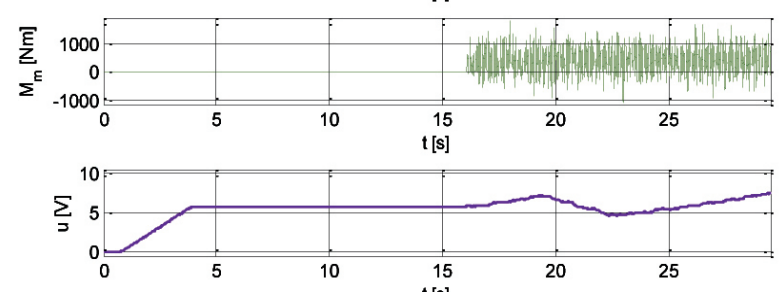

$\mathrm{t}[\mathrm{s}]$

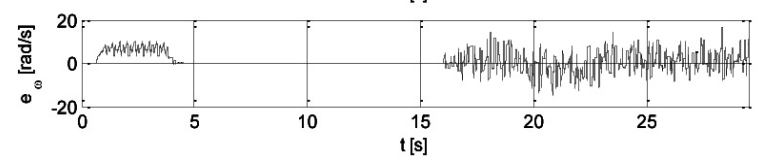

Rys. 8. Odtwarzane podczas badań metoda HIL przebiegi wartości zadanej $\omega_{\text {ref }}$ prędkości kątowej $\omega_{m}$ modelu uktadu napędowego obciażonego momentem

oporowym $M_{m}(t)$ w postaci ciagu czasowego wygenerowanego $z$ wykorzystaniem modelu ARMA

\subsection{Wyniki badań układu zabezpieczeń przed skutkami stanów awaryjnych}

Jednym z istotnych celów badań symulacyjnych metodą HIL jest sprawdzenie reakcji oprogramowania na mogące wystąpić w pracy rzeczywistego układu regulacji stany awaryjne, które nie mogą pozostać bez reakcji sterownika. Stany awaryjne wiążą się z utratą zdolności sterowania. Można tu przykładowo wymienić następujące sytuacje:

- zanik lub zakłócenia sygnałów z czujników pomiarowych (np. czujnika prędkości);

- zanik lub zakłócenia transmisji do elementów wykonawczych (np. przemiennika częstotliwości);

- utrata stabilności układu, czyli oscylacje wielkości wyjściowych na skutek rozbiegania się układu;

- zadziałanie wewnętrznych zabezpieczeń nadprądowych w elemencie wykonawczym (przemienniku częstotliwości).

Wybrane stany awaryjne zostały zasymulowane na stanowisku badawczym. W ramach badań testowych dokonano sprawdzenia działania modułu programowego zabezpieczeń w sytuacji przerwania ciągłości torów układu sterowania, zarówno toru regulacji, jak i toru sprzężenia zwrotnego. Reakcję układu zabezpieczeń na zanik sygnału prędkości w pętli sprzężenia zwrotnego przedstawiono na rysunku 9.

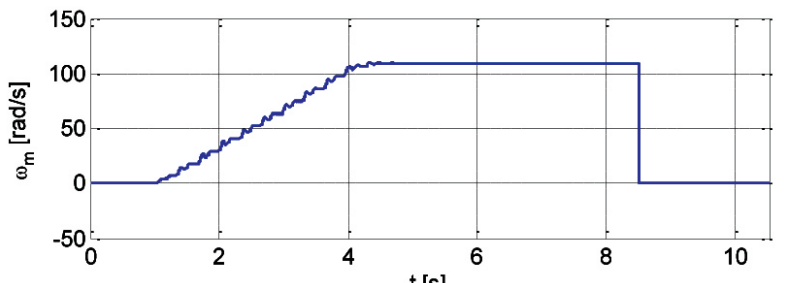

$\mathrm{t}[\mathbf{s}]$

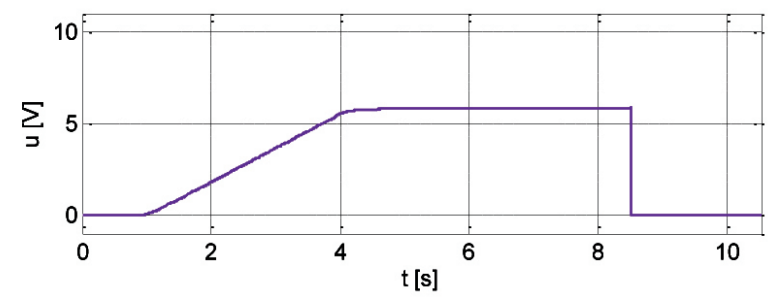

Rys. 9. Przebiegi czasowe prędkości katowej $\omega_{m}$ oraz sygnatu sterujacego $u \mathrm{w}$ sytuacji przerwania pętli sprzężenia zwrotnego (zanik sygnatu z czujnika prędkości)

Utratę stabilności układu osiągnięto przez skokowe zwiększenie wartości nastaw regulatora $\mathrm{w}$ trakcie pracy systemu. Utrata stabilności charakteryzuje się powstawaniem oscylacji o dużej amplitudzie, stąd też jako kryterium detekcji stanu zakłóceniowego przyjęto 
przekroczenie granicznej wartości odchyłki między zadaną a rzeczywistą wartością prędkości kątowej. W każdym z wymienionych stanów awaryjnych reakcja sterownika powinna dążyć do sprowadzenia sygnału sterującego (na wyjściu sterownika) do zera. Zapewnione powinno być również sygnalizowanie wystąpienia stanu awaryjnego oraz wykluczenie możliwości ponownego bezpośredniego uruchomienia urządzenia sterującego przy zaistniałym uszkodzeniu.

Reakcję układu zabezpieczeń na utratę stabilności podczas rozruchu systemu przedstawiono na rysunku 10, a reakcję układu sterowania na utratę stabilności przy obciążeniu momentem oporowym przedstawiono na rysunkach 11 i 12 .
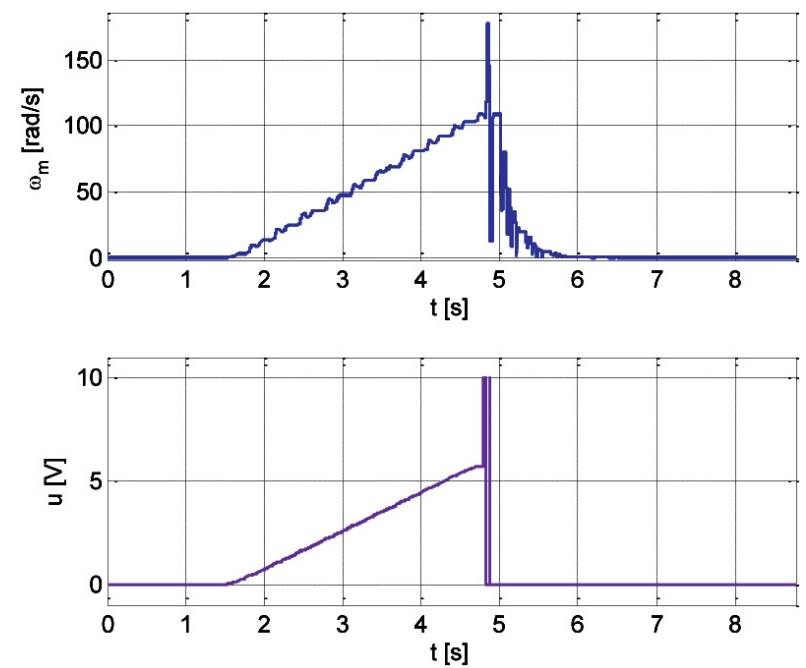

Rys. 10. Przebiegi czasowe prędkości kątowej $\omega_{m}$ oraz sygnatu sterujacego u w sytuacji wykrycia oscylacji prędkości na skutek utraty stabilności podczas rozruchu napędu
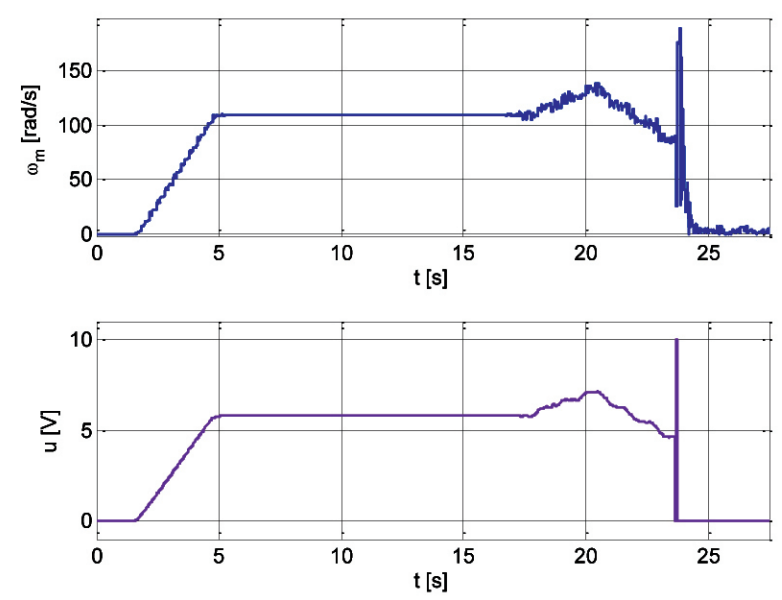

Rys. 11. Przebiegi czasowe prędkości kątowej $\omega_{m}$ oraz sygnału sterujacego u w sytuacji wykrycia oscylacji prędkości na skutek utraty stabilności przy zmniejszajacym się obciażeniu
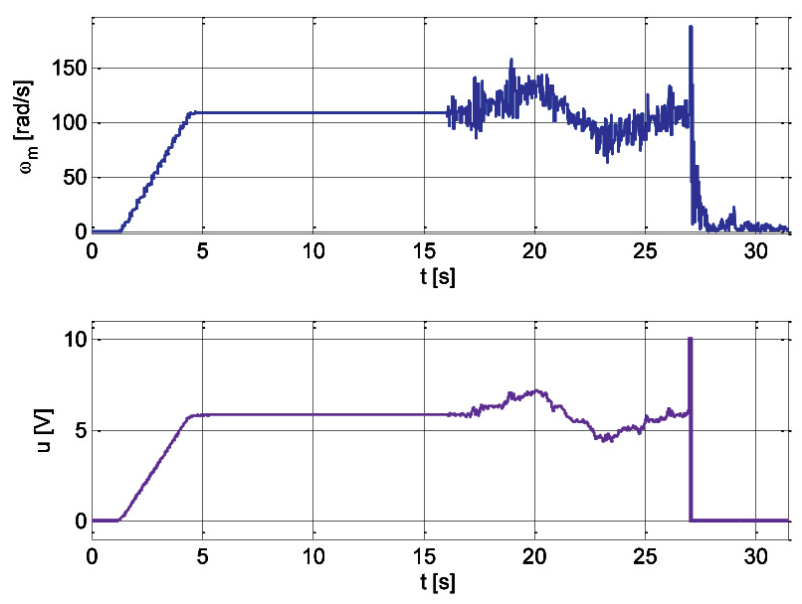

Rys. 12. Przebiegi czasowe prędkości katowej $\omega_{m}$ oraz sygnatu sterującego $u$ w sytuacji wykrycia oscylacji prędkości na skutek utraty stabilności $w$ warunkach narastającego obciażenia

\section{PODSUMOWANIE}

Wyniki badań układu sterowania z regulatorem PI (o nastawach wyznaczonych metodą symulacji MIL) zaimplementowanego w sterowniku $c R I O$ i współpracującego z symulacyjnym cyfrowym modelem układu napędowego kombajnu, wykazują znaczne podobieństwo $\mathrm{z}$ wcześniej uzyskiwanymi wynikami wyznaczonymi metodą MIL. Również zaimplementowane algorytmy zabezpieczeń przed skutkami stanów awaryjnych okazały się efektywne, szybko reagując na zakłócenia i awarie pojawiające się w trakcie pracy kombajnu. Wskazuje to na poprawność opracowania przyjętego algorytmu sterowania i jego implementacji programowej, zastosowanej $\mathrm{w}$ sterowniku przewidzianym do pracy w rzeczywistym układzie.

\section{Podziękowania}

Praca zrealizowana w ramach projektu badawczego pt. „Sterowanie ruchem głowic urabiających kombajnu chodnikowego dla potrzeb obniżenia energochłonności urabiania i obciążeń dynamicznych", dofinansowanego ze środków Narodowego Centrum Badań i Rozwoju w ramach Programu Badań Stosowanych (umowa nr PBS3/B2/15/2015).

\section{Literatura}

[1] Sarhadi P., Yousefpour S.: State of the art: hardware in the loop modeling and simulation with its applications in design, development and implementation of system and control software, „International Journal of Dynamics and Conrol” 2015, 3: $470-479$. 
[2] Jaszczak S.: Procedura Hardware-in-the-Loop w syntezie algorytmów sterowania, „Pomiary - Automatyka - Kontrola” 2010, 56, 7: 685-687.

[3] Pietrusewicz K.: Projektowanie mechatroniczne. Technika Hardware-in-the-Loop a założenia Industry 4.0, „Napędy i Sterowanie" 2016, 4: 92-98.

[4] Bouscayrol A.: Hardware-in-the-Loop simulation, Industrial Electronics Handbook, 2nd ed., Vol. 3, Chapter 35, Taylor \& Francis, Chicago 2011.

[5] Bouscayrol A.: Hardware-in-the-Loop simulation, Electric Vehicle Symposium EVS'24, Stavanger 2009.

[6] Maclay D.: Simulation gets into the loop, „IEEE Review” 1997, 43, 3: 109-112

[7] NI cDAQ ${ }^{\mathrm{TM}}$-9174 Four-Slot USB Chassis Specifications, National Instruments, 2013.

[8] NI cRIO-9074XT Reconfigurable Embedded Chassis with IntegratedIntelligent Real-Time Controller, National Instruments, 2016.

[9] NI 9205 Datasheet 16 AI Differential/32 AI Single-Ended, $\pm 200 \mathrm{mV}$ to $\pm 10 \mathrm{~V}, 16 \mathrm{Bit}, 250 \mathrm{kS} / \mathrm{s}$ Aggregate, National Instruments, 2015.
[10] NI 9263 Datasheet4 AO, \pm 10 V, 16 Bit, 100 kS/s/chSimultaneous, National Instruments, 2016.

[11] AD694 4-20mA transmitter. Datasheet Rev B, Analog Devices Inc, 2002.

[12] Ponce-Cruz P., Molina A., MacCleery B.: Fuzzy Logic Type 1 and Type 2 Based on LabVIEW $W^{\mathrm{TM}}$ FPGA, Springer International Publishing, Heidelberg 2016.

[13] Baran E.D.: LabVIEW FPGA. Riekonfigurirujemyje izmieritielnyje i uprawlajuszczije sistiemy, „DMK Priess”, Moskwa 2009.

dr inż. ADAM HEYDUK

dr inż. JAROSLAW JOOSTBERENS

Katedra Elektrotechniki i Automatyki Przemystowej

Wydziat Górnictwa i Geologii Politechnika Śląka ul. Akademicka 2, 44-100 Gliwice \{Adam.Heyduk, Jaroslaw.Joostberens\}@polsl.pl 